\title{
Angiotensin-Converting Enzyme Inhibitors (ACE-Is) versus Angiotensin- Receptor Blockers (ARBs): Any superiority?
}

\section{Marlene F. Shehata* and Alan Pater}

Clinical Pharmacist Consultant/Cardiovascular Geneticist, Southwestern Ontario

It is well established that renin-angiotensin-aldosterone system (RAAS) blockade with angiotensin-converting enzyme inhibitors (ACE-Is) or angiotensin receptor blockers (ARBs) is beneficial in preventing or reversing endothelial dysfunction and atherosclerosis, thus preventing clinical endpoints such as cardiovascular mortality and morbidity, myocardial infarction and stroke [7,8]. ACE-Is and ARBs reduce end-organ damage in the heart, kidneys and brain $[7,8]$. Despite the different mechanisms of actions of ACE-Is and ARBs, both classes of medications have a blood pressure-lowering effect and both are appropriate for first-line therapy for diastolic and/or systolic hypertension [2]. Moreover, both ACE-Is and ARBs provide renovascular protection and are highly recommended as blood pressure medications in patients with kidney disease.

Except for the recent ONTARGET study (The Ongoing Telmisartan Alone in Combination with Ramipril Global Endpoint Trial) [3], no head-to-head comparisons of ACE-Is and ARBs existed to demonstrate the clinical superiority of one class than the other. Aside from the fact that ARBs were more costly than ACE-[1], clinical superiority was yet to be determined. The ONTARGET trial was able to compare an ACE-I (ramipril) with an ARB (telmisartan). This trial showed that ARBs were not inferior to ACE-Is in efficacy. Both ACE-Is and ARBs behaved similarly in preventing clinical endpoints such as myocardial infarction and stroke in high-risk patients. No difference between ramipril and telmisartan existed in their affecting the rate of syncope and their increasing the risk of hyperkalemia $[3,4,9]$. On the other hand, ARBs had better tolerability profile compared to ACE-Is by their causing lower rates of cough and angioedema [3,4,9]. ARBs were more effective in blood pressure lowering than ACE-Is in the presence of [anti-angiotensin receptor-1 (anti-AT1)] antibodies (usually present in sera of hypertensive patients) [6], but ARBs caused a higher rate of hypotensive symptoms.

It is worth mentioning at this point that the ONTARGET trial studied the impact of a combination therapy with an ACE-I (ramipril) and ARB (telmisartan) in high risk patients [5]. Combination therapy was associated with no added benefits, but rather was associated with more adverse events such as hypotension and syncope that caused a greater number of study discontinuations $[5,9]$. On the contrary, combination therapy using an ACE-I and an ARB was beneficial in reducing mortality and morbidity in chronic heart failure and highrisk diabetes patients $[5,7]$.

In conclusion, despite the higher cost of ARBs than ACE-Is, the better tolerability profile of ARBs than ACE-Is in terms of lower cough rates and angioedema is likely in favour of ARB utilization.

\section{References}

1. Bian B, Kelton CM, Guo JJ, Wigle PR (2010) ACE inhibitor and ARB utilization and expenditures in the medicaid fee-for-service program from 1991 to 2008. Journal of Managed Care Pharmacy: JMCP 16: 671-679.

2. Khan NA, Hemmelgarn B, Herman RJ, Bell CM, Mahon JL, et al. (2009) The 2009 canadian hypertension education program recommendations for the management of hypertension: Part 2--therapy. The Canadian Journal of Cardiology 25: 287-298.

3. ONTARGET Investigators, Yusuf S, Teo KK, Pogue J, Dyal L, et al. (2008) Telmisartan, ramipril, or both in patients at high risk for vascular events. The New England Journal of Medicine 358: 1547-1559.

4. Robles NR, Romero B, Fernandez-Carbonero E, Sanchez-Casado E, Cubero JJ (2009) Angiotensin-converting enzyme inhibitors versus angiotensin receptor blockers for diabetic nephropathy: A retrospective comparison. Journal of the Renin-Angiotensin-Aldosterone System: JRAAS 10: 195-200.

5. Sleight P, Redon J, Verdecchia P, Mancia G, Gao P, et al. (2009) Prognostic value of blood pressure in patients with high vascular risk in the ongoing telmisartan alone and in combination with ramipril global endpoint trial study. Journal of Hypertension 27: 1360-1369.

6. Wei F, Jia XJ, Yu SQ, Gu Y, Wang L, et al. (2011) Candesartan versus imidapril in hypertension: A randomised study to assess effects of anti-AT1 receptor autoantibodies. Heart (British Cardiac Society) 97: 479-484.

7. Werner C, Baumhakel M, Teo KK, Schmieder R, Mann J, et al. (2008) RAS blockade with $A R B$ and ACE inhibitors: Current perspective on rationale and patient selection. Clinical Research in Cardiology: Official Journal of the German Cardiac Society 97: 418-431.

8. Werner C, Poss J, Bohm M (2010) Optimal antagonism of the renin-angiotensinaldosterone system: Do we need dual or triple therapy?. Drugs 70: 1215-1230.

9. White CM, Greene L (2011) Summary of AHRQ's comparative effectiveness review of angiotensin-converting enzyme inhibitors or angiotensin II receptor blockers added to standard medical therapy for treating stable ischemic heart disease. Journal of Managed Care Pharmacy: JMCP 17: S1-15.
*Corresponding author: Marlene Shehata, Clinical Pharmacist Consultant/ Cardiovascular Geneticist, Tel: 519-702-5476; Fax: 347-710-5334; E-mail: marlenefouad@yahoo.com

Received August 08, 2011; Accepted August 20, 2011; Published September 09, 2011

Citation: Shehata MF, Pater A (2011) Angiotensin-Converting Enzyme Inhibitors (ACE-Is) versus Angiotensin-Receptor Blockers (ARBs): Any superiority? J Hypertens 1:e101. doi:10.4172/2167-1095.1000e101

Copyright: (c) 2011 Shehata MF, et al. This is an open-access article distributed under the terms of the Creative Commons Attribution License, which permits unrestricted use, distribution, and reproduction in any medium, provided the original author and source are credited. 